\title{
Cholesterol Transporters ABCA1 and ABCG1 Gene Expression in Peripheral Blood Mononuclear Cells in Patients with Metabolic Syndrome
}

\author{
Zahra Tavoosi, ${ }^{1}$ Hemen Moradi-Sardareh, ${ }^{2}$ Massoud Saidijam, ${ }^{3,4}$ Reza Yadegarazari, ${ }^{4}$ \\ Shiva Borzuei, ${ }^{5}$ Alireza Soltanian, ${ }^{6}$ and Mohammad Taghi Goodarzi ${ }^{3}$ \\ ${ }^{1}$ Department of Clinical Biochemistry, Medical School, Hamadan University of Medical Sciences, Hamadan 65178 38736, Iran \\ ${ }^{2}$ Department of Biochemistry, Medical School, Tehran University of Medical Sciences, Tehran 14176 13151, Iran \\ ${ }^{3}$ Research Center for Molecular Medicine, Hamadan University of Medical Sciences, Hamadan 65178 38736, Iran \\ ${ }^{4}$ Department of Genetics and Molecular Medicine, Hamadan University of Medical Sciences, Hamadan 65178 38736, Iran \\ ${ }^{5}$ Department of Internal Medicine, Medical School, Hamadan University of Medical Sciences, Hamadan 65178 38736, Iran \\ ${ }^{6}$ Department of Biostatistics \& Epidemiology, School of Public Health, Hamadan University of Medical Sciences, \\ Hamadan 65178 38736, Iran
}

Correspondence should be addressed to Mohammad Taghi Goodarzi; mtgoodarzi@yahoo.com

Received 16 August 2015; Revised 24 October 2015; Accepted 17 November 2015

Academic Editor: Maurizio Averna

Copyright (C) 2015 Zahra Tavoosi et al. This is an open access article distributed under the Creative Commons Attribution License, which permits unrestricted use, distribution, and reproduction in any medium, provided the original work is properly cited.

ABCA1 and ABCG1 genes encode the cholesterol transporter proteins that play a key role in cholesterol and phospholipids homeostasis. This study was aimed at evaluating and comparing ABCA1 and ABCG1 genes expression in metabolic syndrome patients and healthy individuals. This case-control study was performed on 36 patients with metabolic syndrome and the same number of healthy individuals in Hamadan (west of Iran) during 2013-2014. Total RNA was extracted from mononuclear cells and purified using RNeasy Mini Kit column. The expression of ABCA1 and ABCG1 genes was performed by qRT-PCR. Lipid profile and fasting blood glucose were measured using colorimetric procedures. ABCG1 expression in metabolic syndrome patients was significantly lower (about 75\%) compared to that of control group, while for ABCA1 expression, there was no significant difference between the two studied groups. Comparison of other parameters such as HDL-C, FBS, BMI, waist circumference, and systolic and diastolic blood pressure between metabolic syndrome patients and healthy individuals showed significant differences $(P<0.05)$. Decrease in ABCG1 expression in metabolic syndrome patients compared to healthy individuals suggests that hyperglycemia, related metabolites, and hyperlipidemia over the transporter capacity resulted in decreased expression of ABCG1. Absence of a significant change in $\mathrm{ABCA1}$ gene expression between two groups can indicate a different regulation mechanism for $\mathrm{ABCA1}$ expression.

\section{Introduction}

The metabolic syndrome (MetS) is defined as a set of interrelated risk factors of diabetes and cardiovascular diseases (CVD) [1]. There are some criteria for clinical diagnosis of metabolic syndrome that include elevated waist circumference ( $\geq 102 \mathrm{~cm}$ in men and $\geq 88 \mathrm{~cm}$ in women), elevated triglycerides $(\geq 150 \mathrm{mg} / \mathrm{dL}$ or $1.7 \mathrm{mmol} / \mathrm{L})$, reduced high density lipoprotein-cholesterol (HDL-C $<40 \mathrm{mg} / \mathrm{dL}$ or $1.03 \mathrm{mmol} / \mathrm{L}$ in men and $<50 \mathrm{mg} / \mathrm{dL}$ or $1.3 \mathrm{mmol} / \mathrm{L}$ in women), and elevated blood pressure ( $\geq 130 \mathrm{~mm} \mathrm{Hg}$ systolic blood pressure or $\geq 85 \mathrm{mmHg}$ diastolic blood pressure) [2]. The MetS can be diagnosed by observation of three of these criteria. In the past several years, the prevalence of MetS increased worldwide $[3,4]$; however, in the United States of America, it has declined from $25.5 \%$ in $1999 / 2000$ to $22.9 \%$ in $2009 / 2010$ [5]. Weiss and colleagues reported that obesity is directly associated with increased prevalence of MetS [6]. There is a reverse association between the CVD and plasma HDL-C level, one of the metabolic syndrome criteria $[7,8]$. High density lipoprotein, a subfraction of circulatory lipoproteins, plays an important role in cholesterol transport 
TABLE 1: Sequence, $T_{m}$, and product length of the used primers in this study.

\begin{tabular}{|c|c|c|c|}
\hline Gene name & Primer sequence & Product length (bp) & $T_{m}\left({ }^{\circ} \mathrm{C}\right)$ \\
\hline \multirow{2}{*}{ ABCA1 } & F: $5^{\prime}$-TGCAAGGCTACCAGTTACATT-3' & \multirow{2}{*}{180} & \multirow{2}{*}{79} \\
\hline & R: 5'-TTAGTGTTCTCAGGATTGGCT-3' & & \\
\hline \multirow{2}{*}{ ABCG1 } & F: $5^{\prime}$-AAGGTGTCCTGCTACATCAT-3' & \multirow{2}{*}{135} & \multirow{2}{*}{81.5} \\
\hline & R: 5'-CAGTATCTCCTTGACCATTTC-3' & & \\
\hline \multirow{2}{*}{ 18S rRNA } & F: $5^{\prime}$-dGTAACCCGTTGAACCCCATT-3' & \multirow{2}{*}{151} & \multirow{2}{*}{64.5} \\
\hline & R: $5^{\prime}$-dCCATCCAATCGGTAGTAGCG-3' & & \\
\hline
\end{tabular}

from peripheral tissue to liver cells [9]. HDL is rich in Apo A-I and Apo A-II proteins, and more than two-thirds of its content is Apo A-I $[10,11]$.

The ABC transmembrane transporters have an important role in cholesterol uptake from macrophage to HDL and decrease the formation of foam cells [10]. ABCA1 composed of 2261 amino acids [12] presents in most tissues. In recent years, it has been shown that ABCA1 plays an essential role in protecting from cardiovascular disease [1]. HDL synthesis directly depends on ABCA1 activity in liver cells; in other words, it has a key function in arterial cells protection against foam cells through increasing plasma HDL. Arterial macrophages ABCAl activity has shown a reverse association with foam cell formation, as with the increase in its activity the formation of foam cell will reduce [11].

The reduced or impaired ABCA1 activity could cause some diseases such as type 2 diabetes [13], Tangier disease $[14,15]$, and premature CVD [16, 17].

ABCG1 gene is located on chromosome 21q22.3 [18]. Both ABCA1 and ABCG1 lead to reduction of tissues cholesterol by its efflux to HDL, but ABCG1 transports tissue cholesterol to $\mathrm{HDL}_{2}$ and $\mathrm{HDL}_{3}$ and $\mathrm{ABCA1}$ transports it to lipid-free Apo A-I $[19,20]$. Macrophages are the most important tissue of ABCA1 and ABCG1 action [21]. In many studies, the effects of upregulation and downregulation of these genes were examined.

Reduced cholesterol efflux is the consequence of lacking ABCA1 expression in vitro $[22,23]$; it can lead to increase in atherosclerosis [23], but upregulation of ABCA1 results in reduction of atherosclerosis [24]. ABCG1 downregulation also has the same effects on cholesterol efflux but there are controversial results about the impact of ABCG1 downregulation on atherosclerosis [25-27].

In MetS, the patterns of expression of some genes change and can lead to obesity, diabetes, and hypertension. In the present study, we aimed to evaluate the ABCA1 and ABCG1 genes expression in patients with MetS, since these genes are involved in the transporters synthesis which have a crucial role in cholesterol transport.

\section{Materials and Methods}

2.1. Subjects. This case-control study was carried out on patients that were referred to an endocrinology ward in a hospital in Hamadan (west of Iran) during 2013-2014. Thirtysix patients with metabolic syndrome were selected. Also, 36 age- and sex-matched healthy individuals were selected as control group. None of the healthy individuals had the criteria of metabolic syndrome.

The inclusion criterion in metabolic syndrome group was having three out of five of the abovementioned characteristics. The patients with history of consumption of antilipid, contraceptive, and diuretic drugs were excluded from the study. The pregnant patients and patients with diabetes, inflammation, and infection were excluded too.

2.2. Blood Sampling. A $2.5 \mathrm{~mL}$ blood sample of each subject was added to an EDTA-containing tube and was kept at $4^{\circ} \mathrm{C}$ for RNA extraction (no more than two hours later).

2.3. Extraction of Peripheral Blood Mononuclear Cells (PBMCs). Lymphodex (Germany) and Henx (Iran) solutions were used for isolation of PBMC. About $2 \mathrm{~mL}$ of Henx solution was added to equal volume of blood and blended completely; then it was poured onto $3 \mathrm{~mL}$ Lymphodex solution carefully and slowly. Subsequently, the mixture was placed on Lymphodex and was centrifuged at $1000 \mathrm{~g}$ for 20 minutes. The intermediate white layer between the plasma and Lymphodex was isolated as mononuclear cells (MCs); then the Henx buffer was added on MC, mixed completely, and centrifuged. Finally, the supernatant was discarded and the process was repeated once more.

2.4. RNA Extraction and cDNA Synthesis. The net extraction of RNA was performed using the Gene JET RNA Purification kit according to the manufacturer protocol. The quality and quantity of the purified RNA were analyzed using NanoSpectrophotometer (Epoch, BioTek, USA); then the integrity of each RNA sample was examined by using $1 \%$ agarose gel, $1 x$ TBE.

The RNA was converted to cDNA using RevertAid First Strand cDNA Synthesis Kit (K1622) through following the protocol: step 1: primer annealing at $25^{\circ} \mathrm{C}$ for $5 \mathrm{~min}$; step 2: cDNA synthesis at $42^{\circ} \mathrm{C}$ for $60 \mathrm{~min}$; step 3: heat inactivation at $70^{\circ} \mathrm{C}$ for $5 \mathrm{~min}$. The products were stored at $-80^{\circ} \mathrm{C}$ for next steps.

2.5. Primer Design. The specific primers for each gene were designed by Allele ID software (version 7.6). In order to increase the specificity of real-time PCR reaction and reduce the false positive results, one of each pair primer was designed to be attached to Exon-Exon junction area. The thorough criteria of the used primers for each gene are presented in Table 1. The 18S rRNA housekeeping gene was used as an internal control. 
TABLE 2: Basic characteristic of the studied groups.

\begin{tabular}{|c|c|c|c|}
\hline Factors & $\begin{array}{c}\text { Control } \\
(\text { mean } \pm \mathrm{SD})\end{array}$ & $\begin{array}{l}\text { Metabolic syndrome } \\
(\text { mean } \pm S D)\end{array}$ & $P$ value \\
\hline Age (year) & $48.5 \pm .25$ & $50.0 \pm 2.02$ & 0.222 \\
\hline Waist circumference $(\mathrm{cm})$ & $95 \pm 1.8$ & $106 \pm 3$ & $0.001^{*}$ \\
\hline BMI $\left(\mathrm{kg} / \mathrm{m}^{2}\right)$ & $25.5 \pm 0.8$ & $30.0 \pm 0.9$ & $0.002^{*}$ \\
\hline Systolic blood pressure (mmHg) & $120.2 \pm 1.9$ & $130.5 \pm 1.6$ & $0.003^{*}$ \\
\hline Diastolic blood pressure $(\mathrm{mmHg})$ & $80.5 \pm 2.1$ & $85.4 \pm 1.1$ & $0.006^{*}$ \\
\hline FBS $(\mathrm{mg} / \mathrm{dL})$ & $91.5 \pm 1.62$ & $108 \pm 3.63$ & $0.001^{*}$ \\
\hline $\mathrm{TG}(\mathrm{mg} / \mathrm{dL})$ & $141 \pm 10.5$ & $187.5 \pm 16.0$ & $0.015^{*}$ \\
\hline HDL-C (mg/dL) & $50.5 \pm 1.35$ & $42.63 \pm 1.50$ & $0.001^{*}$ \\
\hline Total cholesterol (mg/dL) & $189 \pm 8.1$ & $213 \pm 8.0$ & $0.039^{*}$ \\
\hline $\mathrm{LDL}-\mathrm{C}(\mathrm{mg} / \mathrm{dL})$ & $118 \pm 8$ & $128.5 \pm 6$ & 0.096 \\
\hline
\end{tabular}

BMI: Body Mass Index; FBS: Fast Blood Sugar; TG: triglyceride, HDL-C: high density lipoprotein-cholesterol; LDL-C: low density lipoprotein-cholesterol; * significant difference.

The relative expression of the genes was calculated through measuring the threshold cycle (CT) value for each sample using C1000 Thermocycler and CFX96 real-time system (Bio-Rad, USA) and SYBR Premix Ex Taq 2 Kit (TakaRa No. RR820L). The average of CT in triplicate assay of each sample was determined as CT value. The ingredient amounts of qRT-PCR reaction included $10 \mu \mathrm{L}$ SYBR green, $7 \mu \mathrm{L}$ deionized water, and $1 \mu \mathrm{L}$ of each of the forward primer, reverse primer, and template. qRT-PCR was performed in these conditions: initial activation at $95^{\circ} \mathrm{C}$ for $30 \mathrm{sec}$ and then 40 cycles of the following steps repeated: denaturation at $95^{\circ} \mathrm{C}$ for $5 \mathrm{sec}$, annealing at optimized annealing temperature for proper duration of each gene, and extension at $72^{\circ} \mathrm{C}$ for $30 \mathrm{sec}$, and at the end, the data were acquired by increasing temperature from $72^{\circ} \mathrm{C}$ to $95^{\circ} \mathrm{C}$ for $0.5^{\circ} \mathrm{C} / 0.05 \mathrm{sec}$. Then, the PCR products were electrophoresed (on $1 \%$ agarose gel, $1 \mathrm{x}$ TBE) to verify the specificity of amplicons.

2.6. Evaluation of the Serum Biochemical Factors. A twomilliliter blood sample was collected from each subject and centrifuged at $3000 \mathrm{rpm}$ for $10 \mathrm{~min}$ for serum separation. Total cholesterol (TC), LDL-C, TG, FBS, and HDL-C were examined using Pars Azmun (Iran) kit by Hitachi 911 (Germany).

2.7. Analysis and Interpretation of Results. $2^{-\Delta \Delta \mathrm{CT}}$ formula was used for the analysis of the relative gene expression of metabolic syndrome and control groups. The efficiency of real-time PCR was calculated for each gene by using $10^{-2}$ dilution; subsequently, the obtained number was placed at the following computational formula for measuring the fold changes of gene expression [28]:

$$
\begin{aligned}
\Delta \mathrm{CT} & =\mathrm{CT}_{(\text {target })}-\mathrm{CT}_{(\text {reference) }}, \\
\Delta \Delta \mathrm{CT} & =\Delta \mathrm{CT}_{(\text {case })}-\Delta \mathrm{CT}_{(\text {control })}, \\
\text { Fold Change } & =2^{-\Delta \Delta \mathrm{CT}} .
\end{aligned}
$$

SPSS V.16 software was used for statistical analysis with 95\% confidence intervals. Normal distribution of the variables was checked by Kolmogorov-Smirnov method and then the values were compared between two groups via independent samples $t$-test.

\section{Result}

Demographic characteristics and biochemical factors of the studied groups are presented in Table 2 . The male/female ratio was $1 / 3$ in each group (12 M and $24 \mathrm{~F}$ ). As shown in Table 2, the differences in all examined parameters were statistically significant between two groups $(P<0.05)$ with the exception of age and LDL-C. The metabolic syndrome group had higher BMI, LDL-C, TC, TG, FBS, diastolic/diastolic blood pressure, and circumference waist compared to healthy individuals, while HDL-C was significantly lower in metabolic syndrome.

3.1. Results of $q R T-P C R$. After completion of PCR reaction, the results were verified by analysis of the reaction curve, melting curve of products, and electrophoresis of the PCR products. The electrophoresis was run on $1 \%$ agarose using a 100 bp DNA ladder. The results are shown in Figure 1.

3.2. Evaluation of Gene Expression in PBMC. The expression levels of the genes were measured in the peripheral blood mononuclear cells and compared between two groups by calculation of $\triangle \mathrm{CT}$ for each gene. There was no difference in ABCA1 expression between two groups but ABCG1 expression was significantly lower in MetS group $(P=0.02)$. The detailed results are shown in Table 3.

Also, the calculation of fold change in ABCG1 expression $\left(2^{-\Delta \Delta \mathrm{CT}}\right)$ indicated 3.1-fold lower expression in MetS group.

\section{Discussion}

ABCA1 and ABCG1 have a crucial role in cholesterol reverse transport from peripheral tissues such as macrophages to liver [29]. However, ABCA1 and ABCG1 genes expression has been studied in some diseases; we did not find any report on this subject in metabolic syndrome. In this study, 
TABLE 3: Comparison of $\triangle \mathrm{CT}$ of ABCA1 and ABCG1 genes between two studied groups.

\begin{tabular}{lccc}
\hline Gene & Control & Groups & Metabolic syndrome \\
& $12.60 \pm 0.60$ & $12.19 \pm 0.26$ & 0.539 \\
\hline ABCA1 & $14.63 \pm 0.60$ & $12.98 \pm 0.33$ & $0.020^{*}$ \\
\hline
\end{tabular}

${ }^{*}$ Significant.

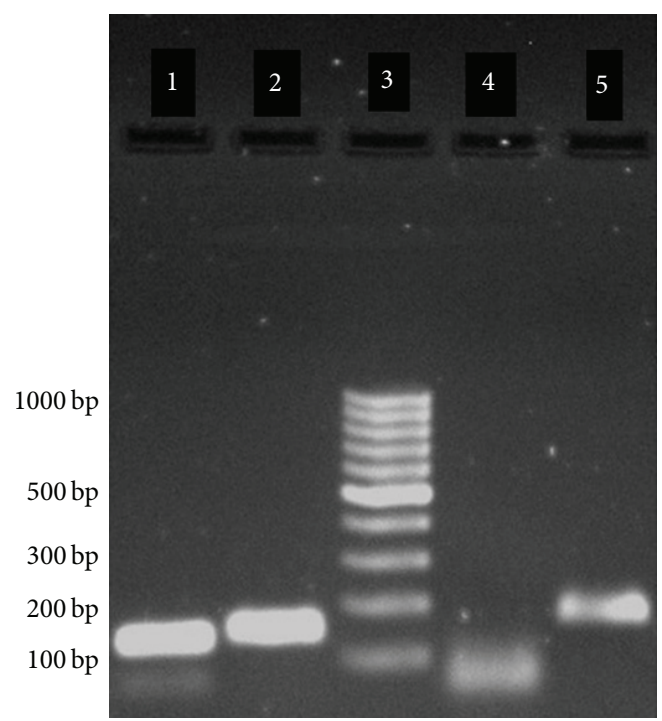

FIgURE 1: Agarose gel electrophoreses of RT-PCR products: lane 1, ABCG1 products with $135 \mathrm{bp}$; lane 2, 18S RNA product with $151 \mathrm{bp}$; lane 3, molecular weight standards with $100-1000 \mathrm{bp}$; lane 4 , negative control with $<100 \mathrm{bp}$; lane $5, \mathrm{ABCA1}$ products with $180 \mathrm{bp}$.

we examined the expression of these genes in metabolic syndrome subjects and healthy individuals.

While there was no significant difference in $\mathrm{ABCA1}$ gene expression between two studied groups, we found significantly lower expression (about $75 \%$ ) of ABCG1 in subjects with metabolic syndrome compared to control group. Singaraja et al. showed that the reduced ABCA1 in macrophages and kidneys is associated with increased cholesterol content [30]. They concluded that impaired ABCA1-mediated cholesterol export could contribute to the increased atherosclerosis and nephropathy associated with diabetes [30]. There are some reports trying to address the possible mechanisms that regulate the expression of these genes. Recently, it has been shown that polymorphisms in $\mathrm{ABCA} 1$ and $\mathrm{ABCC} 8$ may be associated with metabolic syndrome [31]. There is evidence showing that disruption in ABCA1 function, which can be the result of mutation in this gene, can lead to familial hypoalphalipoproteinemia that is characterized by low HDL and increased deposition in cholesteryl esters in several tissues and cells [32]. Also, it has been shown that overexpression of $\mathrm{ABCA1}$ gene can confer protection against atherosclerosis [33]. These data are consistent with our findings and support this idea that lower expression of ABCA1 gene may contribute to metabolic syndrome complications.
Haghpassand et al. demonstrated that $\mathrm{ABCA1}$ gene expression in PBMCs has direct relationship with the load of cholesterol, and overexpression of ABCA1 leads to transfer of the excess cholesterol to the apoproteins [22]. Wang et al. studied the reverse cholesterol transport in ABCAl and ABCG1 knockdown mice and concluded that when both $A B C A 1$ and $A B C G 1$ were knocked down, there is greater reverse cholesterol transport compared to ABCG1 knocked down [29].

Since Mauerer et al. pointed out that the high level of glucose (hyperglycemia) is involved in reduced ABCA1 and ABCG1 expression in vitro [34], it seems logical to expect similar changes in MetS. Promoters of ABCA1 and ABCG1 have receptor site for LXR and RXR; when oxycholesterol and retinoic acid join these factors, expression of $\mathrm{ABCA} 1$ and $\mathrm{ABCG1}$ is increased. Also, cAMP and $\mathrm{NF} \kappa \mathrm{B}$ are transcriptional factors for $\mathrm{ABCA1}$ and $\mathrm{ABCG1}$, respectively.

The obtained results indicated a significant decrease in ABCG1 expression in metabolic syndrome patients compared with healthy individuals. These results suggest that hyperglycemia, related metabolites, and hyperlipidemia over the transporter capacity may lead to decreased expression of ABCG1. Because no significant change was observed in $A B C A 1$ gene expression, it can be due to a different regulation mechanism. Since structures of these genes are different and they are regulated by diverse transcriptional factors, our results can be justified $[35,36]$. Nevertheless, the limited number of the samples in this study is another factor for the absence of changes in ABCA1 expression.

The other point is that we examined the expression of these genes in PBMC of the studied subjects; it is important to notice that the changes in the expression of these genes in monocytes may be different from that in the other key tissues such as liver and intestine, which are the major sites of HDL synthesis. Furthermore, the changes in mRNA levels do not necessarily imply changes in the related protein.

\section{Conflict of Interests}

The authors declare that there is no conflict of interests.

\section{Acknowledgments}

This paper is extracted from Zahra Tavoosi's M.S. thesis. The authors would like to acknowledge Hamadan University of Medical Sciences for financially supporting this study.

\section{References}

[1] K. G. M. M. Alberti, R. H. Eckel, S. M. Grundy et al., "Harmonizing the metabolic syndrome: a joint interim statement of the international diabetes federation task force on epidemiology and prevention; National heart, lung, and blood institute; American heart association; World heart federation; International atherosclerosis society; And international association for the study of obesity," Circulation, vol. 120, no. 16, pp. 1640-1645, 2009.

[2] S. M. Grundy, J. I. Cleeman, S. R. Daniels et al., "Diagnosis and management of the metabolic syndrome: an American Heart 
Association/National Heart, Lung, and Blood Institute scientific statement," Circulation, vol. 112, no. 17, pp. 2735-2752, 2005.

[3] F. de Carvalho Vidigal, J. Bressan, N. Babio, and J. SalasSalvadó, "Prevalence of metabolic syndrome in Brazilian adults: a systematic review," BMC Public Health, vol. 13, no. 1, article 1198, 2013.

[4] A. M. Pimenta, A. Gazzinelli, and G. Velásquez-Meléndez, "Prevalência da síndrome metabólica e seus fatores associados em área rural de Minas Gerais (MG, Brasil)," Ciência \& Saúde Coletiva, vol. 16, no. 7, pp. 3297-3306, 2011.

[5] H. Beltrán-Sánchez, M. O. Harhay, M. M. Harhay, and S. McElligott, "Prevalence and trends of metabolic syndrome in the adult US population, 1999-2010," Journal of the American College of Cardiology, vol. 62, no. 8, pp. 697-703, 2013.

[6] R. Weiss, J. Dziura, T. S. Burgert et al., "Obesity and the metabolic syndrome in children and adolescents," The New England Journal of Medicine, vol. 350, no. 23, pp. 2362-2374, 2004.

[7] P. Barter, A. M. Gotto, J. C. LaRosa et al., "HDL cholesterol, very low levels of LDL cholesterol, and cardiovascular events," The New England Journal of Medicine, vol. 357, no. 13, pp. 1301-1310, 2007.

[8] A. R. Tall, "Cholesterol efflux pathways and other potential mechanisms involved in the athero-protective effect of high density lipoproteins," Journal of Internal Medicine, vol. 263, no. 3, pp. 256-273, 2008.

[9] C. Tang and J. F. Oram, "The cell cholesterol exporter ABCA1 as a protector from cardiovascular disease and diabetes," Biochimica et Biophysica Acta, vol. 1791, no. 7, pp. 563-572, 2009.

[10] G. Schmitz and M. Grandl, "The molecular mechanisms of HDL and associated vesicular trafficking mechanisms to mediate cellular lipid homeostasis," Arteriosclerosis, Thrombosis, and Vascular Biology, vol. 29, no. 11, pp. 1718-1722, 2009.

[11] J. F. Oram and J. W. Heinecke, "ATP-binding cassette transporter A1: a cell cholesterol exporter that protects against cardiovascular disease," Physiological Reviews, vol. 85, no. 4, pp. 1343-1372, 2005.

[12] M. L. Fitzgerald, A. J. Mendez, K. J. Moore, L. P. Andersson, H. A. Panjeton, and M. W. Freeman, "ATP-binding cassette transporter A1 contains an $\mathrm{NH} 2$-terminal signal anchor sequence that translocates the protein's first hydrophilic domain to the exoplasmic space," The Journal of Biological Chemistry, vol. 276, no. 18, pp. 15137-15145, 2001.

[13] D. C. Patel, C. Albrecht, D. Pavitt et al., "Type 2 diabetes is associated with reduced ATP-binding cassette transporter A1 gene expression, protein and function," PLoS ONE, vol. 6, no. 7, Article ID e22142, 2011.

[14] A. Brooks-Wilson, M. Marcil, S. M. Clee et al., "Mutations in $\mathrm{ABC1}$ in Tangier disease and familial high-density lipoprotein deficiency," Nature Genetics, vol. 22, no. 4, pp. 336-345, 1999.

[15] R. M. Lawn, D. P. Wade, M. R. Garvin et al., "The Tangier disease gene product $\mathrm{ABCl}$ controls the cellular apolipoproteinmediated lipid removal pathway," Journal of Clinical Investigation, vol. 104, no. 8, pp. R25-R31, 1999.

[16] A. J. Mendez, "Cholesterol efflux mediated by apolipoproteins is an active cellular process distinct from efflux mediated by passive diffusion," Journal of Lipid Research, vol. 38, no. 9, pp. 1807-1821, 1997.

[17] J. F. Oram, A. J. Mendez, J. Lymp, T. J. Kavanagh, and C. L. Halbert, "Reduction in apolipoprotein-mediated removal of cellular lipids by immortalization of human fibroblasts and its reversion by cAMP: lack of effect with Tangier disease cells," Journal of Lipid Research, vol. 40, no. 10, pp. 1769-1781, 1999.

[18] M. A. Kennedy, A. Venkateswaran, P. T. Tarr et al., "Characterization of the human ABCG1 gene. Liver $\mathrm{X}$ receptor activates an internal promoter that produces a novel transcript encoding an alternative form of the protein," The Journal of Biological Chemistry, vol. 276, no. 42, pp. 39438-39447, 2001.

[19] K. Nakamura, M. A. Kennedy, Á. Baldán, D. D. Bojanic, K. Lyons, and P. A. Edwards, "Expression and regulation of multiple murine ATP-binding cassette transporter G1 mRNAs/isoforms that stimulate cellular cholesterol efflux to high density lipoprotein," Journal of Biological Chemistry, vol. 279, no. 44, pp. 45980-45989, 2004.

[20] N. Wang, D. Lan, W. Chen, F. Matsuura, and A. R. Tall, "ATP-binding cassette transporters G1 and G4 mediate cellular cholesterol efflux to high-density lipoproteins," Proceedings of the National Academy of Sciences of the United States of America, vol. 101, no. 26, pp. 9774-9779, 2004.

[21] A. Venkateswaran, B. A. Laffitte, S. B. Joseph et al., "Control of cellular cholesterol efflux by the nuclear oxysterol receptor LXR $\alpha$," Proceedings of the National Academy of Sciences of the United States of America, vol. 97, no. 22, pp. 12097-12102, 2000.

[22] M. Haghpassand, P.-A. K. Bourassa, O. L. Francone, and R. J. Aiello, "Monocyte/macrophage expression of ABCA1 has minimal contribution to plasma HDL levels," Journal of Clinical Investigation, vol. 108, no. 9, pp. 1315-1320, 2001.

[23] M. Van Eck, I. S. T. Bos, W. E. Kaminski et al., "Leukocyte ABCA1 controls susceptibility to atherosclerosis and macrophage recruitment into tissues," Proceedings of the National Academy of Sciences of the United States of America, vol. 99, no. 9, pp. 6298-6303, 2002.

[24] M. Van Eck, R. R. Singaraja, D. Ye et al., "Macrophage ATP-binding cassette transporter Al overexpression inhibits atherosclerotic lesion progression in low-density lipoprotein receptor knockout mice," Arteriosclerosis, Thrombosis, and Vascular Biology, vol. 26, no. 4, pp. 929-934, 2006.

[25] M. Ranalletta, N. Wang, S. Han, L. Yvan-Charvet, C. Welch, and A. R. Tall, "Decreased atherosclerosis in low-density lipoprotein receptor knockout mice transplanted with $A b c g 1^{-1-}$ bone marrow," Arteriosclerosis, Thrombosis, and Vascular Biology, vol. 26, no. 10, pp. 2308-2315, 2006.

[26] Á. Baldán, L. Pei, R. Lee et al., "Impaired development of atherosclerosis in hyperlipidemic $\mathrm{Ldlr}^{-1-}$ and $\mathrm{ApoE}^{-/-}$mice transplanted with $A b c g 1^{-/-}$bone marrow," Arteriosclerosis, Thrombosis, and Vascular Biology, vol. 26, no. 10, pp. 2301-2307, 2006.

[27] R. Out, M. Hoekstra, R. B. Hildebrand et al., "Macrophage ABCG1 deletion disrupts lipid homeostasis in alveolar macrophages and moderately influences atherosclerotic lesion development in LDL receptor-deficient mice," Arteriosclerosis, Thrombosis, and Vascular Biology, vol. 26, no. 10, pp. 2295-2300, 2006.

[28] K. J. Livak and T. D. Schmittgen, "Analysis of relative gene expression data using real-time quantitative PCR and the $2^{-\Delta \Delta C_{\mathrm{T}}}$ method," Methods, vol. 25, no. 4, pp. 402-408, 2001.

[29] X. Wang, H. L. Collins, M. Ranalletta et al., "Macrophage ABCA1 and ABCG1, but not SR-BI, promote macrophage reverse cholesterol transport in vivo," The Journal of Clinical Investigation, vol. 117, no. 8, pp. 2216-2224, 2007.

[30] R. R. Singaraja, C. Fievet, G. Castro et al., "Increased ABCA1 activity protects against atherosclerosis," Journal of Clinical Investigation, vol. 110, no. 1, pp. 35-42, 2002. 
[31] C. Tang, J. E. Kanter, K. E. Bornfeldt, R. C. Leboeuf, and J. F. Oram, "Diabetes reduces the cholesterol exporter ABCA1 in mouse macrophages and kidneys," Journal of Lipid Research, vol. 51, no. 7, pp. 1719-1728, 2010.

[32] O. Deger, Y. E. Yandi, M. Ayvaz, C. Erem, and A. B. Hacihasanoğlu, "Polymorphisms in ABC transporters (ABCA1 and ABCC8) in metabolic syndrome," Turkish Journal of Medical Sciences, vol. 43, no. 2, pp. 214-221, 2013.

[33] M. Wang and M. R. Briggs, "HDL: the metabolism, function, and therapeutic importance," Chemical Reviews, vol. 104, no. 1, pp. 119-137, 2004.

[34] R. Mauerer, S. Ebert, and T. Langmann, "High glucose, unsaturated and saturated fatty acids differentially regulate expression of ATP-binding cassette transporters ABCA1 and ABCG1 in human macrophages," Experimental and Molecular Medicine, vol. 41, no. 2, pp. 126-132, 2009.

[35] P. Costet, Y. Luo, N. Wang, and A. R. Tall, "Sterol-dependent transactivation of the $\mathrm{ABCl}$ promoter by the liver $\mathrm{X}$ receptor/retinoid X receptor," The Journal of Biological Chemistry, vol. 275, no. 36, pp. 28240-28245, 2000.

[36] J. F. Oram and A. M. Vaughan, "ATP-binding cassette cholesterol transporters and cardiovascular disease," Circulation Research, vol. 99, no. 10, pp. 1031-1043, 2006. 


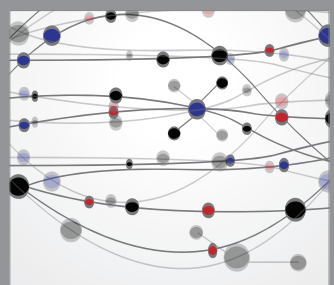

The Scientific World Journal
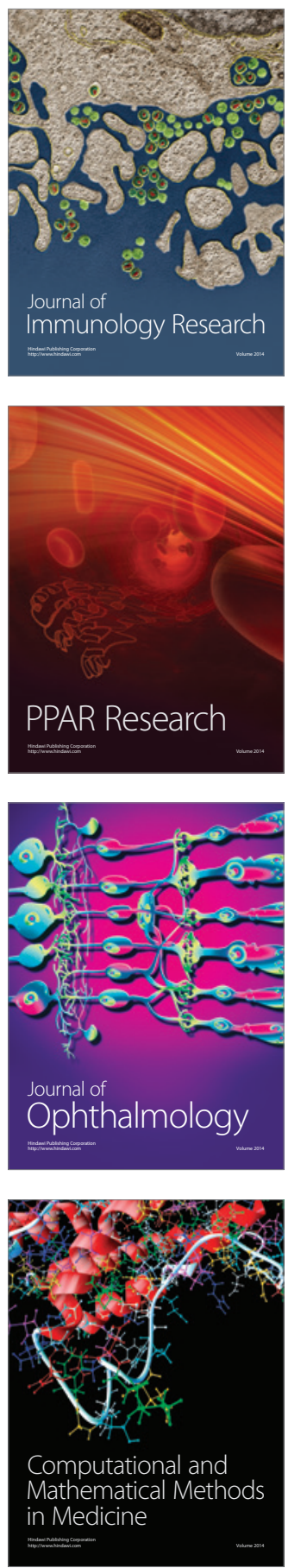

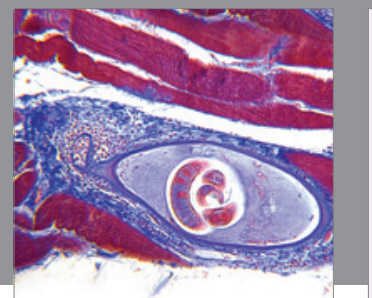

Gastroenterology

Research and Practice
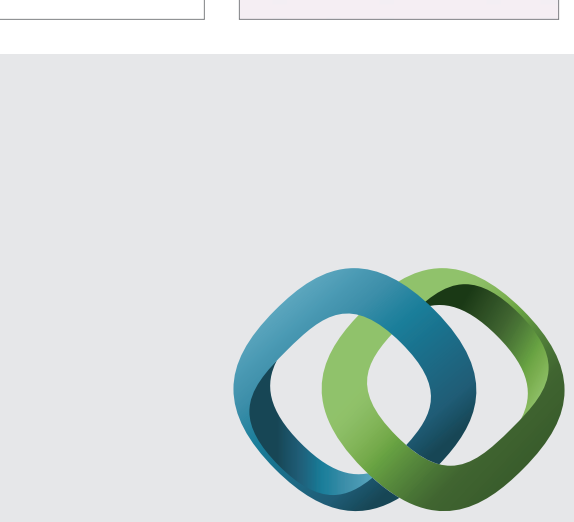

\section{Hindawi}

Submit your manuscripts at

http://www.hindawi.com
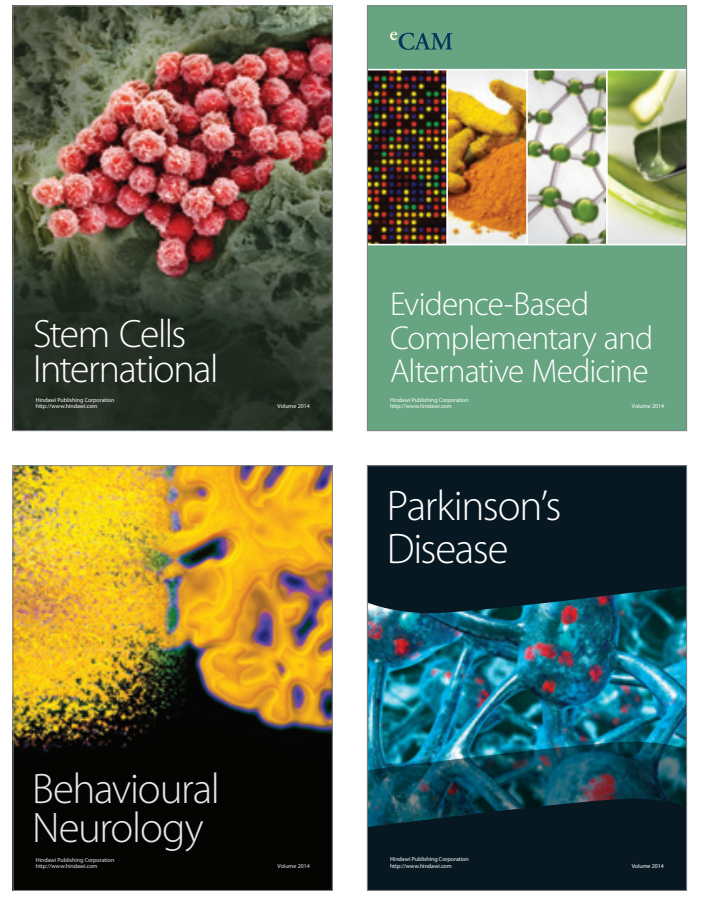
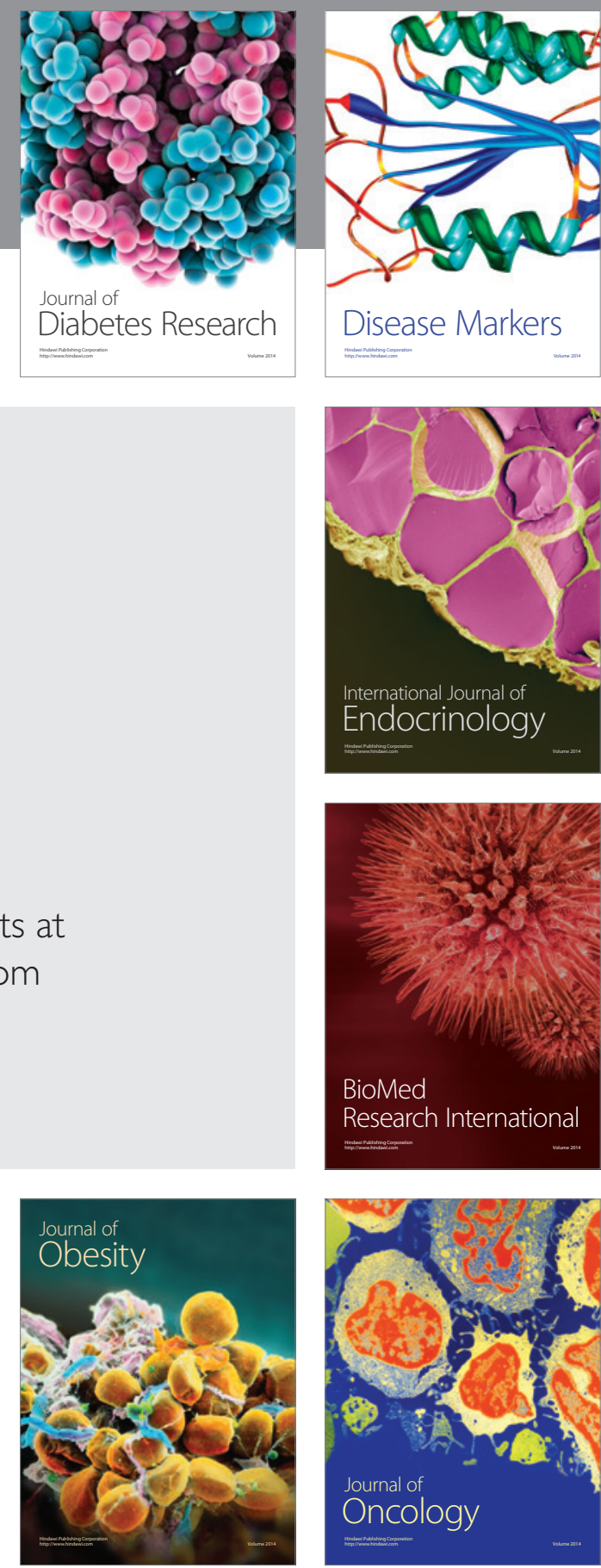

Disease Markers
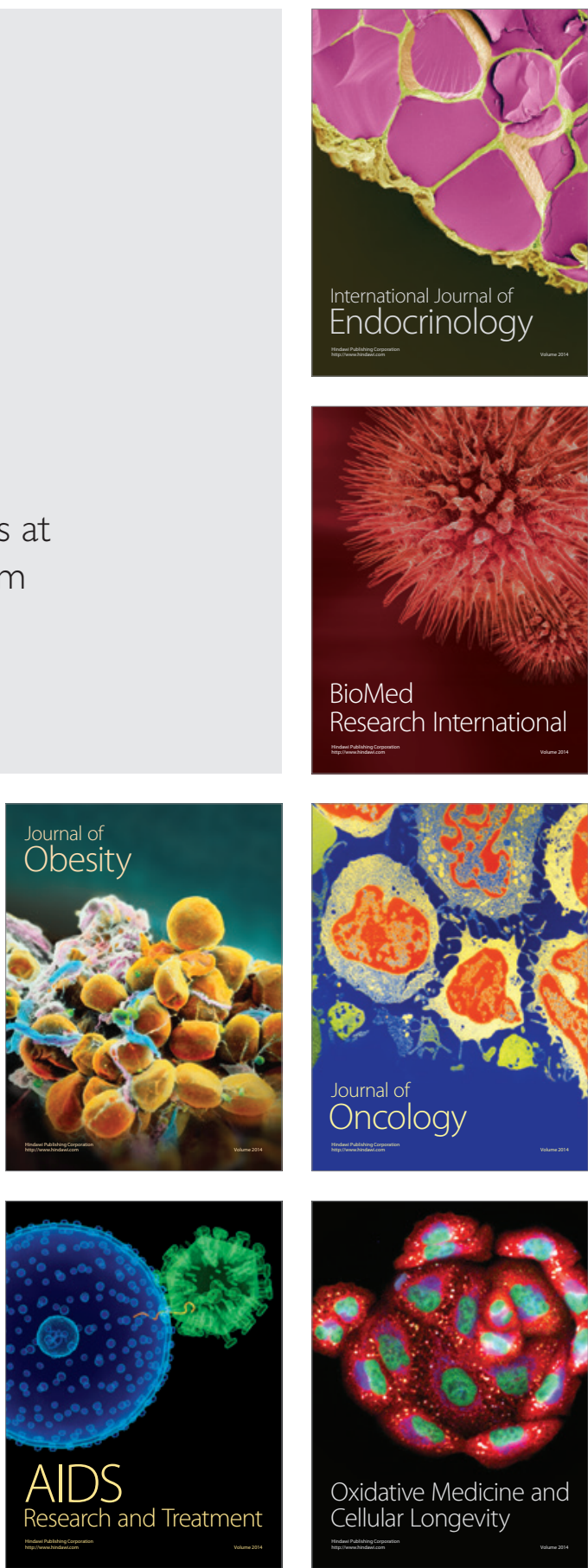